\title{
LINGKUNGAN SEKOLAH DALAM MEMBENTUK PERILAKU SOSIAL SISWA
}

\author{
Nunu Nurfirdaus ${ }^{1}$, Atang Sutisna ${ }^{2}$ \\ STKIP Muhammadiyah Kuningan \\ Correspondence Email: nunu@upmk.ac.id
}

\begin{abstract}
Abstrak
Lingkungan Sekolah dalam Membentuk Perilaku Sosial Siswa. Tujuan dari penelitian ini adalah untuk dapat mendeskripsikan tentang peran lingkungan sekolah dalam pembentukan perilaku sosial siswa. Lokasi penelitian dilaksanakan di SDN 2 Luragung Kecamatan Luragung Kabupaten Kuningan. Metode yang digunakan dalam penelitian ini adalah studi kasus. Teknik pengumpulan data yaitu observasi, wawancara mendalam dan dokumentasi, dengan informan siswa, guru, dan tokoh masyarakat setempat yang ditentukan secara purposive sampling. Dalam penelitian ini menggunakan teori Bourdieu habitus dan arena, dimana habitusnya adalah kegiatan di sekolah dan arenanya adalah lingkungan sekolah tersebut. Hasil penelitian menunjukkan perilaku sosial siswa merupakan segala bentuk kegiatan yang dilakukan siswa dalam situasi sosial tertentu. Perilaku sosial seseorang akan dapat terbentuk dengan berbagai faktor, baik faktor eksternal maupun internal, artinya perilaku seseorang akan terus dapat menyesuaikan dirinya dengan berbagai situasi sosial. Peranan lingkungan sekolah terhadap pembentukan perilaku sosial siswa di lingkungan sekolah seperti: keteladanan, pembiasaan, nasehat, mekanisme kontrol, memberi sanksi terlaksana secara baik dan sistematis. Elemen masyarakat sebagai salah satu pengapliaksian dari sikap-sikap sosial siswa menjadi bagian yang tidak terpisahkan dan ikut berperan sebagai kontrol dari sikap-sikap sosial tersebut.
\end{abstract}

Kata Kunci:

Lingkungan Sekolah, Perilaku Sosial

\begin{abstract}
School Environment in Shaping Student Social Behavior. The purpose of this study is to describe the role of the school environment in shaping students' social behavior. The research location was conducted at SDN 2 Luragung, Luragung District, Kuningan Regency. The method used in this research is a case study. The data collection techniques were observation, in-depth interviews and documentation, with student informants, teachers and local community leaders who were determined by purposive sampling. In this study, the theory of Bordieu habitus and arena is used, where the habitus is the activity in the school and the arena is the school environment. The results showed that students' social behavior was all forms of activities carried out by students in certain social situations. A person's social behavior will be formed by various factors, both external and internal, meaning that a person's behavior will continue to be able to adapt himself to various social situations. The role of the school environment in shaping the social behavior of students in the school environment, such as: modeling, habituation, advice, control mechanisms, giving sanctions are carried out well and systematically. Community elements as one of the applications of students' social attitudes are an integral part and play a role as control of these social attitudes.
\end{abstract}

Keywords:

School Environment, Social Behavior

\section{A. PENDAHULUAN}

Lingkungan merupakan salah satu faktor yang berpengaruh terhadap perkembangan anak. Salah satunya faktor eksternal. Faktor eksternal terdiri dari dua macam yaitu faktor lingkungan sosial dan faktor lingkungan non sosial. Lingkungan sosial terbentuk dari lingkungan keluarga, guru, dan masyarakat. Sedangkan lingkungan non 
sosial terbentuk dari sarana dan prasarana. Anak belajar untuk menjalani kehidupan melalui interaksi dengan lingkungan. Lingkungan sosial yang lebih banyak mempengaruhi kegiatan belajar adalah orang tua dan keluarga siswa itu sendiri. Dari keluarga inilah baik dan buruknya perilaku dan kepribadian anak terbentuk. Walaupun ada juga faktor lain yang mempengaruhi proses terbentuknya perilaku dan pribadi anak seperti halnya sarana dan prasarana yang tidak memenuhi standar kompetensi.

Manusia sebagai makhluk individu dan sosial akan menampilkan tingkah laku tertentu, akan terjadi peristiwa pengaruh mempengaruhi antara individu yang satu dengan individu yang lain. Hasil dari peristiwa saling mempengaruhi tersebut maka timbulah perilaku sosial tertentu yang akan mewarnai pola interaksi tingkah laku setiap individu. Perilaku sosial individu akan ditampilkan apabila berinteraksi dengan orang lain. Dalam hal ini individu akan mengembangkan pola respon tertentu yang sifatnya cenderung konsisten dan stabil sehingga dapat ditampilkan dalam situasi sosial yang berbeda-beda.

Perilaku sosial merupakan suatu bentuk tindakan atau interaksi yang berhubungan dengan orang lain. Pembentukan perilaku sosial seseorang dipengaruhi oleh berbagai faktor baik yang bersifat internal maupun yang bersifat eksternal. Lingkungan utama yang sangat bertanggung jawab terhadap kelangsungan pendidikan baik di dunia atau khususnya di Indonesia yaitu keluarga, masyarakat dan pemerintah (Sekolah) ketiganya itu sering disebut dengan Tripusat pendidikan yang masing-masing lingkungan tersebut memiliki peran yang sama dan saling melengkapi.
Tripusat pendidikan adalah istilah yang dikemukakan oleh Ki Hajar Dewantara. Konsep Tripusat Pendidikan Ki Hajar Dewantara memiliki arti yaitu pendidikan di lembaga pendidikan (sekolah), pendidikan di masyarakat, dan pendidikan di keluarga. Ketiganya sering disebut sebagai lingkungan pendidikan sosial siswa, dimana pendidikan berlangsung pada tiga lingkungan tersebut. Tripusat pendidikan adalah tiga unsur penting yang sangat berperan dalam pendidikan dan menjadi pusat kegiatan pendidikan.

Perilaku sosial seseorang akan dapat terbentuk dengan berbagai faktor, baik faktor eksternal maupun internal, artinya kepribadian seseorang masih sangat dikatakan labil, karena pada hakikatnya manusia sebagai makhluk sosial dan individu, akan terus dapat menyesuaikan dirinya dengan berbagai situasi sosial. Terutama untuk anak usia sekolah dasar yang memang masih dalam fase perkembangan operasional konkret. Pada usia tersebut masih sangat memungkinkan seseorang akan mengikuti apa yang dilakukan oleh orang-orang di lingkungan sekitarnya bukan tidak mungkin pula untuk dapat diarahkan.

Adapun lingkungan sekolah merupakan bagian dari sosial, sehingga sekolah juga mempunyai peran dalam membentuk karakter dan perilaku siswa. Pendapat di atas menjelaskan peran guru sebagai bagian dari sekolah dan yang berhubungan langsung dengan siswa di kelas mempunyai tanggung jawab besar dalam membentuk karakter, kepribadian dan perilaku siswa. Oleh karena itu, sudah selayaknya bila setiap guru mempertimbangkan dan mengaitkan antara kondisi dan lingkungan siswa 
dengan karakter yang akan dikembangkan.

Lingkungan sekolah harus dapat menjadi wahana yang dapat mengembangkan segala potensi dari seorang anak didiknya. Sedangkan lingkungan pendidikan adalah berbagai faktor yang berpengaruh terhadap pendidikan atau berbagai lingkungan tempat berlangsungnya proses pendidikan. Jadi lingkungan sekolah adalah kesatuan ruang dalam lembaga pendidikan formal yang memberikan pengaruh pembentukan sikap dan pengembangan potensi siswa. Dari itu melalui program-program sekolah diharapkan dapat menjadikan anak didik yang berperilaku unggul.

Pergaulan, pertemanan, interaksi, lingkungan dan yang lainnya saling memberikan pengaruh satu dengan yang lainnya, dengan demikian hal ini perlu dilakukan analisis peranan lembaga pendidikan terhadap pembentukan perilaku sosial anak. Peranan lembaga pendidikan mempunyai tugas sebagai pengarah, pembimbing dan tentu sebagai pemberi teladan baik untuk seluruh warga sekolahnya melalui program-program sekolah yang dilakukan secara rutin. Hal ini tentu akan berpengaruh pada perkembangan sosial emosional anak, dengan melihat bagaimana perilaku siswa dalam lingkungan sekolah maupun di lingkungan masyarakat sekitarnya. Berdasarkan uraian diatas maka peneliti merasa perlu untuk melakukan penelitian mengenai: "Lingkungan Sekolah dalam Membentuk Perilaku Sosial Siswa”.

\section{B. HASIL PEMBAHASAN}

\section{Lingkungan Sekolah}

$\begin{array}{lrr}\text { Sekolah adalah } & \text { lembaga } \\ \text { pendidikan secara } & \text { resmi } \\ \text { menyelenggarakan } & \text { kegiatan } \\ \text { pembelajaran secara } & \text { sistematis, }\end{array}$

berencana, sengaja dan terarah yang dilakukan oleh pendidik yang profesional dengan program yang dituangkan ke dalam kurikulum tertentu dan diikuti oleh peserta didik pada setiap jenjang tertentu, mulai dari tingkat anak-anak sampai perguruan tinggi. Lingkungan keluarga merupakan dasar pembentukan sikap dan sifat manusia, lingkungan sekolah merupakan tempat bekal keahlian dan ilmu pengetahuan, sedangkan lingkungan masyarakat merupakan tempat praktek dari bekal yang diperoleh dalam keluarga dan sekolah sekaligus sebagai tempat pengembangan kemampuan diri. Koordinasi antar lingkungan tersebut menciptakan keselarasan dan keserasian dalam menjadikan manusia yang berpendidikan dan dan berkepribadian unggul.

Lingkungan sekolah sebagai mana mestinya harus dapat menjadi wahana yang dapat mengembangkan segala potensi dari seorang anak didiknya. Sedangkan lingkungan pendidikan adalah berbagai faktor yang berpengaruh terhadap pendidikan atau berbagai lingkungan tempat berlangsung proses pendidikan. Jadi lingkungan sekolah adalah kesatuan ruang dalam lembaga pendidikan formal yang memberikan pengaruh pembentukan sikap dan pengembangan potensi siswa. Maka dari itu melalui program-program sekolah diharapkan dapat menjadikan anak didik yang berperilaku unggul.

Adapun lingkungan sekolah merupakan bagian dari sosial, sehingga sekolah juga mempunyai peran dalam membentuk karakter dan perilaku siswa. Pendapat di atas 
menjelaskan peran guru sebagai bagian dari sekolah dan yang berhubungan langsung dengan siswa di kelas mempunyai tanggung jawab besar dalam membentuk karakter, kepribadian dan perilaku siswa. Oleh karena itu, sudah selayaknya bila setiap guru mempertimbangkan dan mengaitkan antara kondisi dan lingkungan siswa dengan karakter yang akan dikembangkan. Seorang anak belajar kemandirian lebih intensif di lingkungan sekolah dibandingkan dengan tempat lain.

Lingkungan sekolah memiliki peranan penting dalam pembentukan perilaku sosial siswa, sehingga dari tujuan pendidikan dapat terwujudkan dengan maksimal. Semua warga sekolah harus dapat melaksanakan apa yang menjadi tugas daripada dirinya. Kepala sekolah bertindak sebagai kepala sekolah yang dapat mengawasi dan membuat kebijakan bagaimana program sekolah dapat terealisasi. Guru sebagai model teladan untuk para siswanya, serta masyarakat disekitar lingkungan sekolah dapat meninjau bagaimana kegiatan kependidikan di sekolah tersebut. Sekolah merupakan sebuah lembaga yang mempunyai peranan penting dalam kehidupan siswa. Karena sekolah merupakan tempat kedua selain keluarga dalam pembentukan perilaku dan pribadi anak.

\section{Pada kegiatan wawancara} dengan Guru Kelas V SDN 2 Luragung menuturkan:
"Lingkungan sekolah akan sangat berpengaruh bagaimana temannya di lingkungan sekolah, ibu bapak guru bagaimana sikapnya tentu akan meniru apa yang dia lihat di lingkungan sekolahnya. Tentu dengan komunikasi akan dapat mendorong pembentukan perilaku menuju ke lebih baik".

Pengembangan potensi siswa, pembentukan perilaku sosial siswa dapat dilakukan melalui kegiatan rutin sekolah sebagai berikut: pertama, upacara bendera yang dilakukan setiap hari Senin. Dalam upacara bendera, siswa dibiasakan untuk disiplin, tertib, tanggung jawab dan mencintai tanah airnya Indonesia, hal ini dapat dilihat saat siswa mengikuti kegiatan ini. Menurut kepala sekolah upacara menjadi kegiatan strategis untuk membiasakan anak dalam berperilaku baik. Bukan hanya itu, tetapi sebagai sarana untuk komunikasi kepala sekolah untuk menyapa seluruh siswa secara bersamaan.

Budaya literasi. Kegiatan membaca buku menjadi hal yang tidak terpisahkan karena salah satu cara untuk membentuk perilaku sosial siswa di SDN 2 Luragung agar memiliki wawasan luas, dibiasakan untuk membaca buku. Kegiatan ini dilakukan sebelum pembelajaran dimulai dan pada saat istirahat siswa yang telah selesai makan jajanan atau yang tidak jajan mengisi waktu istirahat dengan membaca buku yang disediakan di depan kelas atau membaca di perpustakaan sekolah.

Shalat dhuha bersama dan yasinan. Masih dalam kecerdasan 
spiritual dengan pembiasaan pada kegiatan keagamaan, siswa dibimbing untuk shalat dhuha dan membaca Al Qur'an surat yasin secara bersama. Kegiatan ini dilakukan setiap hari Jumat. Perilaku sosial siswa adalah tindakan atau aktivitas dari manusia itu sendiri yang mempunyai bentangan yang sangat luas antara lain: berjalan, berbicara, menangis, tertawa, bekerja, belajar, menulis, membaca, dan sebagainya atau singkatnya perilaku sosial merupakan semua kegiatan atau aktivitas manusia, baik yang diamati langsung, maupun yang tidak dapat diamati oleh pihak luar. Di lingkungan sekolah, siswa melakukan banyak kegiatan yang tidak lain adalah bagian dari proses pembentukan perilaku sosialnya. Melalui proses pembelajaran di kelas, kegiatan keagamaan, serta semua program yang ditetapkan di sekolah tersebut, itu semua adalah proses pembentukan perilaku sosial siswa.

\section{Perilaku Sosial Siswa}

Sebagai makhluk sosial, seorang individu sejak lahir hingga sepanjang hayatnya senantiasa berhubungan dengan individu lainnya atau dengan kata lain melakukan relasi interpersonal. Dalam relasi interpersonal itu ditandai dengan berbagai aktivitas tertentu, baik aktivitas yang dihasilkan berdasarkan naluriah semata atau justru melalui proses pembelajaran tertentu.

Perilaku sosial (dalam Tu'u, 2004: 12) adalah suasana saling ketergantungan yang merupakan keharusan untuk menjamin keberadaan manusia. Sebagai bukti bahwa manusia dalam memenuhi kebutuhan hidup sebagai diri pribadi tidak dapat melakukannya sendiri melainkan memerlukan bantuan dari orang lain. Ada ikatan saling ketergantungan antara satu orang dengan yang lainnya. Artinya bahwa kelangsungan hidup manusia berlangsung dalam suasana saling mendukung dalam kebersamaan. Untuk itu manusia dituntut mampu bekerja sama, saling menghormati, tidak mengganggu hak orang lain, toleran dalam hidup bermasyarakat.

Berdasarkan penjelasan tersebut, maka dapat disimpulkan bahwa perilaku sosial adalah tindakan atau aktivitas dari manusia itu sendiri yang mempunyai bentangan yang sangat luas antara lain: berjalan, berbicara, menangis, tertawa, bekerja, belajar, menulis, membaca, dan sebagainya atau singkatnya perilaku sosial adalah semua kegiatan atau aktivitas manusia, baik yang diamati langsung, maupun yang tidak dapat diamati oleh pihak luar.

Sejak dilahirkan manusia membutuhkan pergaulan dengan orang lain untuk memenuhi kebutuhan biologisnya. Pada perkembangan menuju kedewasaan, interaksi sosial diantara manusia dapat merealisasikan kehidupannya secara individual. Hal ini dikarenakan jika tidak ada timbal balik dari interaksi sosial maka manusia tidak dapat merealisasikan potensi-potensinya sebagai sosok individu yang utuh sebagai hasil interaksi sosial. Potensi-potensi itu pada awalnya dapat diketahui dari perilaku kesehariannya. Pada saat bersosialisasi maka yang ditunjukkannya adalah perilaku 
sosial. Pembentukan perilaku sosial seseorang dipengaruhi oleh berbagai faktor, baik yang bersifat internal maupun yang bersifat eksternal.

Manusia sebagai makhluk individu dan sosial akan menampilkan tingkah laku tertentu, akan terjadi peristiwa pengaruh mempengaruhi antara individu yang satu dengan individu yang lain. Hasil dari peristiwa saling mempengaruhi tersebut maka timbulah perilaku sosial tertentu yang akan mewarnai pola interaksi tingkah laku setiap individu. Perilaku sosial individu akan ditampilkan apabila berinteraksi dengan orang lain. Dalam hal ini individu akan mengembangkan pola respon tertentu yang sifatnya cenderung konsisten dan stabil sehingga dapat ditampilkan dalam situasi sosial yang berbeda-beda.

Berbagai aktivitas individu dalam relasi interpersonal ini biasa disebut perilaku sosial. Dengan demikian, perilaku sosial individu dilihat dari kecenderungan peranan (role disposition) dapat dikatakan memadai, manakala menunjukkan ciri-ciri respons interpersonal sebagai berikut : 1) yakin akan kemampuannya dalam bergaul secara sosial; 2) memiliki pengaruh yang kuat terhadap teman sebaya; 3) mampu memimpin teman-teman dalam kelompok; dan 4) tidak mudah terpengaruh orang lain dalam bergaul. Sebaliknya, perilaku sosial individu dikatakan kurang atau tidak memadai manakala menunjukkan ciri-ciri respons interpersonal sebagai berikut: 1) kurang mampu bergaul secara sosial; 2) mudah menyerah dan tunduk pada perlakuan orang lain;
3) pasif dalam mengelola kelompok; dan 4) tergantung kepada orang lain bila akan melakukan suatu tindakan.

Perilaku sosial adalah perilaku yang relatif menetap yang diperlihatkan oleh individu di dalam berinteraksi dengan orang lain. Orang yang berperilakunya mencerminkan keberhasilan dalam proses sosialisasinya dikatakan sebagai orang yang sosial, sedangkan orang yang perilakunya tidak mencerminkan proses sosialisasi tersebut disebut non sosial. Yang termasuk ke dalam perilaku non sosial adalah perilaku a-sosial dan anti sosial. Seseorang yang berperilaku asosial tidak mengetahui apa yang yang dituntut oleh kelompok sosial, sehingga berperilaku yang tidak memenuhi tuntutan sosial. Mereka akan mengisolasi diri atau menghabiskan waktunya untuk menyendiri. Sedangkan yang berperilaku anti sosial mereka mengetahui hal-hal yang dituntut kelompok tetapi karena sikap permusuhannya, mereka melawan norma kelompok tersebut.

\section{Lingkungan dalam pembentukan perilaku sosial siswa}

Sekolah merupakan lingkungan pendidikan yang diharapkan mampu melahirkan manusia yang seutuhnya yang memiliki kecerdasan intelektual (IQ), kecerdasan emosional (EQ), dan kecerdasan spiritual (SQ). Pengertian sekolah itu ada dua. Pertama, lingkungan fisik dengan berbagai perlengkapan yang merupakan tempat penyelenggaraan proses pendidikan untuk usia dan kriteria tertentu. 
Kedua, proses kegiatan belajar mengajar.

Lingkungan merupakan faktor yang berpengaruh terhadap perkembangan anak. Salah satunya faktor eksternal. Faktor eksternal terdiri dari dua macam yaitu faktor lingkungan sosial dan faktor lingkungan non sosial. Lingkungan sosial terbentuk dari lingkungan keluarga, guru, dan masyarakat. Sedangkan lingkungan non sosial terbentuk dari sarana dan prasarana. Anak belajar untuk menjalani kehidupan melalui interaksi dengan lingkungan. Lingkungan sosial yang lebih banyak mempengaruhi kegiatan belajar adalah orang tua dan keluarga siswa itu sendiri. Dari keluarga inilah baik dan buruknya perilaku dan kepribadian anak terbentuk. Walaupun ada juga faktor lain yang mempengaruhi proses terbentuknya perilaku dan pribadi anak seperti halnya sarana dan prasarana yang tidak memenuhi standar kompetensi.

Lingkungan yang kedua setelah lingkungan keluarga dikenal anak adalah sekolah. Sekolah mempunyai pengaruh yang sangat besar terhadap perkembangan kepribadian anak didik. Di sekolah siswa melakukan berbagai kegiatan untuk mencapai keberhasilan belajar. Dalam proses belajar muncul sikap dan perilaku siswa yang mengganggu proses belajarnya di kelas. Perilaku siswa yang mengganggu proses belajar mengajar tersebut perilakunya menyimpang. Perilaku menyimpang tersebut ada yang berpengaruh terhadap dirinya sendiri dan ada yang berpengaruh pada orang lain.
Lingkungan sekolah adalah sebagai arena (ranah) dalam pembentukan perilaku sosial. Ranah merupakan: (1) arena kekuatan sebagai upaya perjuangan untuk memperebutkan sumber daya atau modal dan juga untuk memperoleh akses tertentu yang dekat dengan hirarki kekuasaan; (2) semacam hubungan yang terstruktur dan tanpa disadari mengatur posisi-posisi individu dan kelompok dalam tatanan warga sekolah yang terbentuk secara spontan.

Pengembangan potensi siswa, pembentukan perilaku sosial siswa dapat dilakukan melalui kegiatan rutin sekolah seperti kegiatan upacara bendera yang dilakukan setiap hari Senin. Dalam upacara bendera, siswa dibiasakan untuk disiplin, tertib, tanggung jawab dan mencintai tanah airnya Indonesia.

Selain itu budaya literasi juga merupakan salah satu kebiasaan siswa yang akan membentuk perilaku sosial dimana kegiatan membaca buku menjadi hal yang tidak terpisahkan karena salah satu cara untuk membentuk perilaku sosial siswa di SDN 2 Luragung agar memiliki wawasan luas, dibiasakan untuk membaca buku. Kegiatan ini dilakukan sebelum pembelajaran dimulai dan pada saat istirahat siswa yang telah selesai makan jajanan atau yang tidak jajan mengisi waktu istirahat dengan membaca buku yang disediakan di depan kelas atau membaca di perpustakaan sekolah.

\section{KESIMPULAN}

Perilaku sosial siswa merupakan segala bentuk kegiatan yang dilakukan siswa dalam situasi sosial tertentu. Perilaku sosial seseorang akan dapat 
terbentuk dengan berbagai faktor, baik faktor eksternal maupun internal, artinya perilaku seseorang akan terus dapat menyesuaikan dirinya dengan berbagai situasi sosial. Peranan lingkungan sekolah terhadap pembentukan perilaku sosial dapat diwujudkan dengan membentuk kebiasaan-kebiasaan yang baik yang dilakukan dilingkungan sekolah dengan kebiasaan- yang baik tersebut diharapkan pembentukan perilaku sosial pada siswa akan menunjukkan kepada perilaku sosial yang baik.

Selain itu keluarga juga memiliki peran penting dalam pembentukan perilaku sosial siswa, lingkungan keluarga yang memiliki waktu cukup banyak dalam aktivitas siswa dibandingkan dengan lingkungan sekolah merupakan hal yang tidak bisa dipisahkan dalam pembentukan perilaku sosial siswa. Bagaimana keluarga menjadi kontrol dan contoh teladan yang baik dalam perilaku sosial siswa

\section{DAFTAR PUSTAKA}

Adib, Mohammad. Tanpa tahun. Agen dan Struktur dalam Pandangan Piere Bourdieu. BioKultur, Vol.I/No.2/Juli- Desember.

Aditia, Fajar. 2017. Kebiasaan siswa dalam pembentukan perilaku sosial siswa. Kuningan: STKIP Muhammadiyah Kuningan.
Hasbullah. 2006. Dasar-dasar Ilmu Pendidikan. Jakarta: Raja Grafindo Persada.

Marjohan, 2014. Hubungan Keteladanan Orang Tua Terhadap Perilaku Sosial Siswa. Jurnal Ilmiah PPKn IKIP Veteran Semarang. Volume 2 nomor 1.

Moleong, Lexy J. 2017. Metodologi Penelitian Kualitatif Edisi Revisi. Bandung: PT Remaja Rosdakarya.

Nahar, Novi Irwan. 2016. Penerapan Teori Belajar Behavioristik Dalam Proses Pembelajaran. Nusantara (Jurnal Ilmu Pengetahuan Sosial) Volume 1 Desember 2016. ISSN 2541-657X.

Oktaviana, 2015. Pengaruh Lingkungan Sekolah Terhadap Motivasi Belajar Siswa Kelas V Sekolah Dasar Di Daerah Binaan I Kecamatan Limpung Kabupaten Batang. Semarang: UNNES.

Permana, Yudi, dkk. 2015. Model-model Pembelajaran IPS di Sekolah Dasar. Bandung: UPI Press.

Slameto, 2010. Belajar dan Faktor-faktor yang Mempengaruhinya. Jakarta: Rineka Cipta.

Sugiyono. 2015. Metode Penelitian Administrasi dilengkapi dengan Metode R \& D. Bandung: Alfabeta.

Tatang S. 2012. Ilmu Pendidikan. Bandung: CV Pustaka Setia.

Tu'u, Tulus. 2004. Peran Disiplin Pada Siswa Perilaku dan Prestasi Siswa. Jakarta: PT Grasindo. 